\title{
HIGH PREVALENCE OF DNA FROM NON-H. pylori HELICOBACTERS IN THE GASTRIC MUCOSA OF VENEZUELAN PET DOGS AND ITS HISTOLOGICAL ALTERATIONS
}

\author{
Rito POLANCO(1), Víctor SAlAZAR(2), Nelson REYES(3), María Alexandra GARCíA-AMADO(3), Fabián MiCHELANGELI(3) \& Monica CONTRERAS(3)
}

\begin{abstract}
SUMMARY
Non-H. pylori helicobacters (NHPH) have been demonstrated as gastric spiral-shaped bacteria in specimens obtained from dogs; however, their roles in the pathogenesis of upper gastrointestinal disease have not yet been clearly established. The purpose of this study was to evaluate the prevalence of NHPH DNA in the gastric mucosa of dogs and its association with histopathology. Helicobacter was detected through histopathological techniques, PCR, and FISH analysis from fundic biopsies of twenty dogs with or without signs of gastrointestinal disease. PCR and FISH were based on partial 16S rRNA gene sequences. Nineteen dogs showed mild to marked gastritis in the fundus, and only one dog had a healthy gastric mucosa. NHPH DNA was detected in 18 dogs with gastritis and one with normal gastric mucosa. However, there was no significant correlation between the presence of NHPH DNA and the degree of gastritis. These results show a high prevalence of NHPH DNA in the gastric mucosa of dogs from Venezuela. Further studies are necessary to determine a possible association between a specific NHPH species and the degree of gastritis.
\end{abstract}

KEYWORDS: Gastric NHPH; 16S rDNA; Gastritis; Dogs; Venezuela.

\section{INTRODUCTION}

Helicobacter spp. colonizes the stomach and intestine of humans and several animal species ${ }^{14}$. The Helicobacter genus currently stands at about 38 formally named members with numerous other putative species under investigation ${ }^{18}$. A variety of gastric non- $H$. pylori helicobacters (NHPH) can infect the stomach (fundus, corpus and antrum) of pets, but their role in the pathogenesis of upper gastrointestinal disease is unclear $^{24}$. H. felis, H. bizzozeronii, H. salomonis, H. heilmannii sensu stricto (s.s.), $H$. cynogastricus and $H$. baculiformis are gastric NHPH species commonly found in dogs and cats, while $H$. suis often colonizes the stomach mucosa of pigs ${ }^{2,15,27}$. All canine and feline associated gastric NHPH have been detected in the human stomach, except for $H$. cynogastricus and $H$. baculiformis, which have not yet been found ${ }^{14}$. Moreover, H. heilmanni s.s. and $H$. felis have been associated with gastritis in animals, and mainly in the antral mucosa from humans ${ }^{12}$.

The prevalence of gastric NHPH in dogs and cats is high $(>70 \%)$ and may not correlate with clinical signs and severity of gastritis ${ }^{16}$. However, the majority of these species are difficult to culture and, identification depends mostly on phylogenetic analysis to discriminate between the same species. Therefore, a growing number of gastric NHPH has been detected by genus-specific PCR assays, fluorescence in situ hybridization (FISH) targeting the $16 \mathrm{~S}$ rRNA gene and sequencing of $16 \mathrm{~S}$ and $23 \mathrm{~S}$ rRNA-encoding genes and specific genes, such as $h s p 60, \operatorname{gyr} B$ and ure $A B^{14}$. Although the prevalence of gastric NHPH infection has been reported in dogs from different developed countries, little is known about the presence of NHPH in pet dogs from developing countries ${ }^{23}$. The aim of this study was to evaluate the prevalence of NHPH in the gastric mucosa of dogs from Venezuela and investigate its association with histopathological alterations.

\section{MATERIALS AND METHODS}

Animals: Clinical studies and sample collection were carried out at the Unidad de Investigación Quirúrgica Veterinaria de la Universidad Nacional Experimental "Francisco de Miranda" (UNEFM). Twenty pet dogs (nine males and 11 females; range, 0.8-9 years), nine with vomiting and 11 clinically healthy were recruited into this study. None of these dogs had been treated with antibiotics, corticosteroids, or antacids within the three weeks preceding sample collection. Gastric mucosal (fundus) biopsy specimens were taken for histological evaluation and rapid urease testing by Ure-IVIC $1^{10}$. Samples were collected with Olympus endoscopes, GFX II (Japan) with standard 0.8-mm endoscopic biopsy forceps, during routine endoscopic examination of anesthetized dogs. Three mucosal biopsy specimens were obtained endoscopically from the stomach (fundus) of each animal; one was fixed in formaldehyde for histopathology and FISH, one was used for rapid urease testing by HelicoTest $^{\mathrm{TM}}$ (formerly Ure-IVIC ${ }^{10}$ ), and one for DNA extraction and polymerase chain reaction (PCR) assays. The two last samples were

(1) Unidad de Investigación Quirúrgica Veterinaria de la Universidad Nacional Experimental "Francisco de Miranda" (UNEFM), Falcón, Venezuela.

(2) Servicio de Microscopía de Luz.

(3) Laboratorio de Fisiología Gastrointestinal, Centro de Biofísica y Bioquímica, Instituto Venezolano de Investigaciones Científicas (IVIC), Miranda, Venezuela.

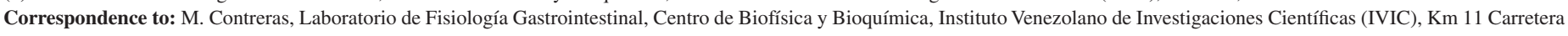
Panamericana, Altos de Pipe, Miranda, Venezuela. Apdo. 21827, Caracas 1020A. Tel.: +58-212-504-1855. Fax: +58-212-504-1020. E-mail: mocontre@ ivic.gob.ve 


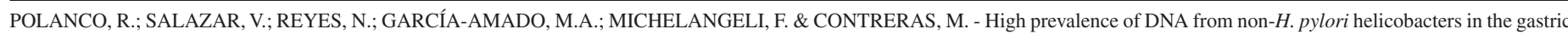
mucosa of Venezuelan pet dogs and its histological alterations. Rev. Inst. Med. Trop. Sao Paulo, 53(4): 207-12, 2011.

immediately frozen in dry ice and subsequently stored at $-80{ }^{\circ} \mathrm{C}$ until experimental procedures were performed at IVIC. Clinical and sample collection protocols were previously approved by the UNEFM Bioethics Committee.

Histopathology: The fundus samples were fixed in formalin and embedded in Paraplast ${ }^{\mathrm{TM}}$ medium (Sigma, St. Louis, MO). Sections of each sample, $4 \mu \mathrm{m}$ in thickness, were obtained and adhered onto Clearcell Thermo Fisher printed slides (Thermo Fisher Scientific, Portsmouth, $\mathrm{NH}$ ), dewaxed in xylene ( $3 \times 10$ minutes), and subsequently rehydrated in $100 \%$ ( $3 \times 10$ minutes), $70 \%$ ethanol, and lastly in phosphate buffer solution $\mathrm{pH} 7.4$ (PBS). The sections were used for FISH, and for staining by hematoxylin-eosin (H\&E) and Warthin-Starry's techniques. The histopathological parameters were analyzed according to the World Small Animal Veterinary Association (WSAVA) guidelines ${ }^{6}$. The degree of morphological features and inflammatory changes were graded by using the WSAVA gastrointestinal standardization visual analog scale for normal, mild, moderate, and marked inflammation with a scoring system from 0 to 3 , respectively.

Fluorescence-in Situ-hybridization (FISH): FISH was performed as previously described ${ }^{30}$. Briefly, the following treatments were performed before FISH: Immersion of the sections in $264 \mathrm{mM}$ Sodium borohydryde for 20 minutes, $0.01 \%$ Triton X100 for 10 minutes, and 25\% proteinase $\mathrm{K}$ for five minutes. Sections were rinsed three times with PBS at room temperature between steps. Three fluorescent oligonucleotide probes targeting the bacterial 16S rRNA gene were used in this study: two Helicobacter genus-specific probes, HEL274 (Cy3-5' labeled) and HEL717 (Cy3-5' labeled) to determine the presence of Helicobacter species in the gastric mucosa ${ }^{5}$, and a probe for the universal bacteria domain EUB338 (AlexaFluor 488, N-5' labeled) as a positive control and to simultaneously visualize bacteria within intact tissue samples ${ }^{1}$. The probes were commercially synthesized by Integrated DNA Technologies (Dallas, TX). Hybridization was performed at $54{ }^{\circ} \mathrm{C}$ for 90 minutes and stringent washing at $56{ }^{\circ} \mathrm{C}$ for 10 minutes according to the protocol as described previously ${ }^{30}$. The bacteria were visualized with a Nikon Eclipse E600 epi-fluorescence microscope using cubes B-2A, G-2A and UV-2A for Alexa-488, Cy3 and DAPI respectively: the images were digitally acquired by a Nikon Coolpix 8700 camera. Probe specificity was verified by evaluating positive control (eg, slide prepared from a clinical strain culture of $H$. pylori) and negative control [slide prepared from a strain culture of Shigella sp. (ATCC11126)]. The fixation of control strains was performed according to a protocol described previously ${ }^{26}$.

PCR assays: DNA from fundic biopsies was extracted using the QIAamp DNA Mini Kit according to the manufacturer's instructions (Qiagen Inc, Valencia, CA). Helicobacteraceae and Helicobacter DNA were detected using family- and genus-specific PCR assays targeting $764 \mathrm{bp}$ and $399 \mathrm{bp}$ fragments of the $16 \mathrm{~S}$ rRNA gene $\mathrm{g}^{4,13}$. The presence of $H$. pylori DNA was ruled by using specific assays targeting a $294 \mathrm{bp}$ fragment of the $\operatorname{glm} M$ gene and a $128 \mathrm{bp}$ fragment of the $\operatorname{cagA}$ gene $^{22,25}$. PCRs were performed using the Ready To-Go PCR beads kit (Amersham Biosciences Corp., Piscataway, NJ) in a thermal cycler model GeneAMP PCR System 9700 (Applied Biosystems, Hayward, CA). The positive control was $H$. pylori DNA and the negative control was a no-template PCR reaction. The amplicons were visualized by running the reaction mixture in a TBE agarose gel $(2.0 \%)$, staining with ethidium bromide, and observing them using an UV transilluminator.
$16 S$ rRNA gene sequencing and sequence analysis: Helicobacteraceae-specific fragments (764 bp) of the 16S rRNA gene amplified were purified for sequencing using the QIAquick PCR Purification Kit (QIAquick PCR Purification Kit, Qiagen Inc, Valencia, $\mathrm{CA}$ ), according to the manufacturer's recommendations. The primers used for sequencing of both DNA strands were BohrF (C97-20) and BohrR (H3A-20), as previously described ${ }^{4}$. Both strands of all nineteen purified amplicons were sequenced at the CeSAAN facility (IVIC, Altos de Pipe, Venezuela) with an ABI PRISM ${ }^{\mathrm{TM}} 3130 x 1$ Sequencer (Applied Biosystems, Foster, CA). Sequences were compared with the compilation of 16S rRNA gene sequences available in the GenBank nucleotide library by BLAST searching. The $16 \mathrm{~S}$ rRNA gene sequences ( 600-711 bp) of 19 amplicons were deposited in GenBank under the accession numbers GQ181184-GQ181202.

Phylogenetic analysis: Dog sequences together with closest GenBank matches were aligned in the greengenes website (http:// greengenes.lbl.gov) using a multiple sequence alignment server for comparative analysis of $16 \mathrm{~S}$ rRNA genes ${ }^{8}$. Chimera check was performed in the greengenes website ${ }^{9}$. The phylogenetic tree was constructed using the neighbor-joining method and the Jukes-Cantor model provided in Molecular Evolutionary Genetics Analysis 2.1 software (MEGA, version $4.0)^{29}$, and the stability of grouping was estimated by bootstrap analysis (500 replications) using the same program.

Statistical analyses: A dog was considered infected if two or more test results were positive. The association between NHPH species detected and gastritis grade was evaluated by Spearman's rank correlation test. This was considered positive when $p \leq 0.05$.

\section{RESULTS}

Histopathological observations: Of the 20 dogs studied, only one (5\%) presented a normal mucosa whereas $19(95 \%)$ had histopathological changes representative of various degrees of gastritis in the fundic region of the stomach (Table 1). Of these, seven (36.84\%) dogs had mild gastritis, which was associated mainly with diffuse intraepithelial lymphocytes infiltration and scarce leukocytes and focal degeneration of the surface epithelium (Fig. 1A). Two dogs (10.53\%) had moderate gastritis, evidenced by epithelial degeneration, isolated glandular tissue, showing the presence of bacteria adhering to epithelial cells (Fig. 1B), whereas $10(52.63 \%)$ presented marked gastritis, characterized by necrosis of the epithelium of the gastric pit; nested, atrophic and sparse lobules of glandular tissue, diffused lymphocyte infiltration, and glandular atrophy (Fig. 1C and D). Examination of hematoxylin-eosin (Fig. 2A and B) and Warthin-Starry (Fig. 2C and D) stained sections revealed

Table 1

Degree of gastritis and Helicobacter infection in dogs $(\mathrm{n}=20)$

\begin{tabular}{lcc}
\hline Degree of gastritis & Non-infected & Infected \\
\hline Normal & 0 & 1 \\
Mild & 0 & 7 \\
Moderate & 0 & 2 \\
Marked & 1 & 9 \\
Total & 1 & 19 \\
\hline
\end{tabular}




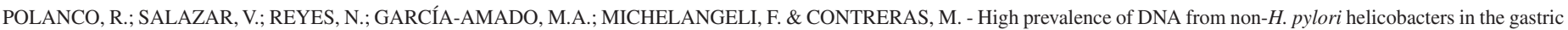
mucosa of Venezuelan pet dogs and its histological alterations. Rev. Inst. Med. Trop. Sao Paulo, 53(4): 207-12, 2011.

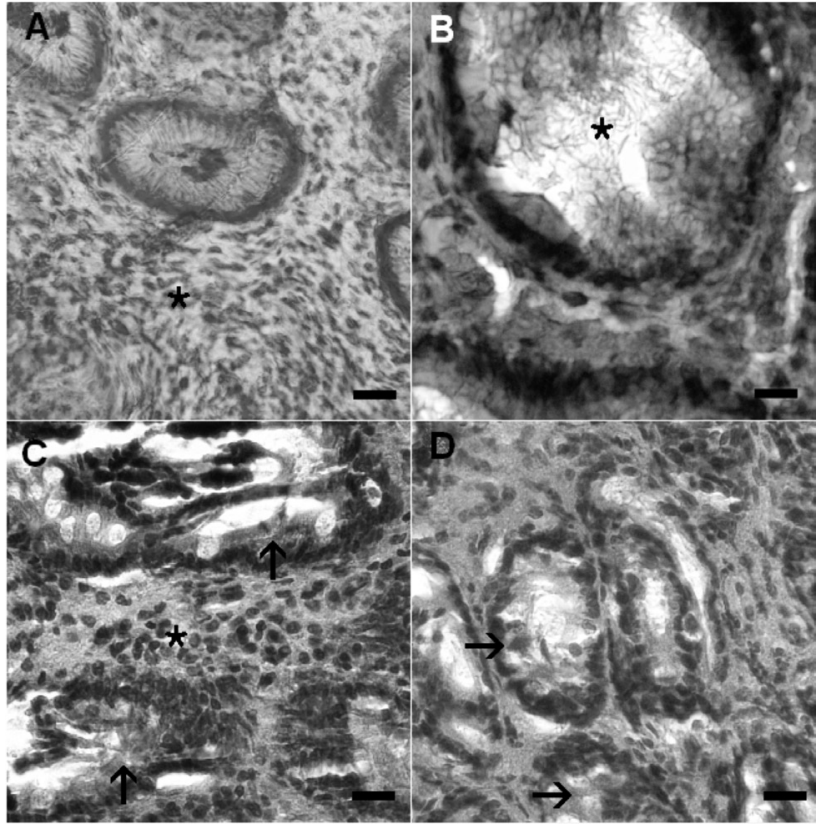

Fig. 1 - Gastric mucosa (fundus) biopsy sections; H\&E stained. (A) Mucosa with mild gastritis with diffuse mononuclear cell infiltration (asterisk). (B) Gastric tissue with moderate gastritis showing the massive presence of bacteria (asterisk) adhering to epithelial cells. (C) Gastric tissue section showing marked gastritis with infiltration of inflammatory cells (asterisk) and glandular atrophy (arrows). (D) Necrosis of mucosa in marked gastritis; the arrows indicate destruction of epithelium in an infiltration zone. Bars: A, B, and C: $15 \mu \mathrm{m}$; D: $30 \mu \mathrm{m}$.

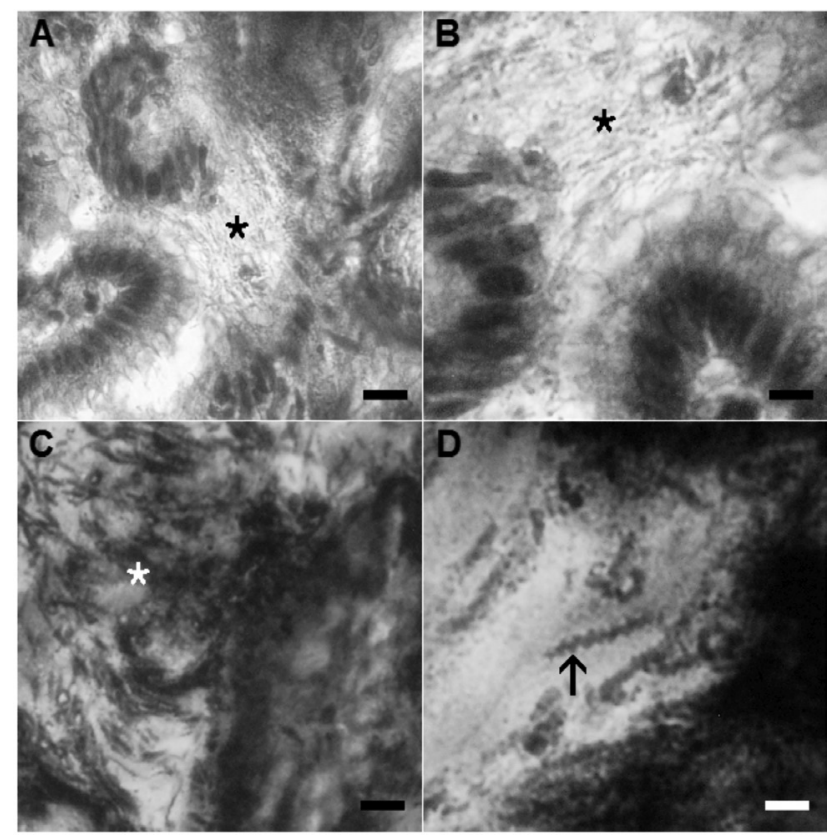

Fig. 2 - Gastric mucosa (fundus) biopsy sections. (A) Gastric tissue section stained by H\&E showing massive presence of spiral-shaped bacteria in the gastric mucosa (asterisk). (B) Detail of image in A showing spiral-shaped bacteria. (C) Gastric tissue section stained by Warthin-Starry's technique showing the presence of spiral-shaped bacteria in the gastric mucosa (asterisk). (D) Detail of image in C, showing the spiral-shaped bacteria (arrow). Bars: A: $25 \mu \mathrm{m}$; B, and C: $5 \mu \mathrm{m}$; D: $2.5 \mu \mathrm{m}$. spiral-shaped bacteria in 19 out of 20 biopsies examined. In only one case with marked gastritis bacteria were not detected by these methods. However, there was a significant correlation between mild gastritis and the presence of bacteria $(r=-0.572 ; p=0.0083)$, but there was no statistical relationship between the degree of gastritis and clinical signs (vomiting) (mild $r=-0.0316 ; p=0.8948$, moderate $r=0.1830 ; p=0.4400$, marked $r=-0.0101 ; p=0.9662)$.

NHPH infection status: Seventeen of the 20 dogs showed positive for NHPH by all four tests used to detect infection (histology, rapid urease test, PCR and FISH). Two out of 20 dogs were urease-negative, but these were positive for histology, PCR and FISH. While one dog showed urease-positive, NHPH were not found by histology, PCR or FISH (Table 2). NHPH DNA was detected by Helicobacteraceae family- and Helicobacter genus-specific PCR in 19 out of 20 dogs examined, except in one case where one sample was only PCR-positive for Helicobacteraceae (Table 2). The $\operatorname{cag} A$ and $g \operatorname{lm} M$ genes were not detected in any of the 19 Helicobacter infected dogs. FISH was carried out on all fundic biopsies from 20 dogs to detect a fragment of the 16S rDNA from Helicobacter species. The probes HEL274/HEL717 were able to detect Helicobacter in 19 out of 20 infected dogs (Fig. 3). Helicobacter was observed as red whole-cell with different morphology (spiral-shaped or round organisms) and distributed in the fundus within the luminal area and/or close to the surface of mucus layer covering the secretory epithelium, adhering to epithelial cells, and to mononuclear cells in the submucosa and lamina propia (Fig. 3B and C). FISH was concordant with histology and PCR. Almost all of the animals were NHPH infected (19/20) by these criteria and only one was not infected (1/20); this individual case was insufficient to allow comparisons. NHPH DNA was detected in $18 \mathrm{dogs}$ with gastritis and one with normal gastric mucosa, whereas one dog had gastritis but NHPH infection was not detected (Table 1). There was no statistical relationship between the presence of gastritis and NHPH infected dogs $(r=-0.0526 ; p=0.8256)$.

Sequence analysis: The 16S rRNA partial gene sequences obtained in 19 dogs were amplified by PCR using Helicobacteraceae familyspecific primers. The length of the sequences obtained ranged from 600 to $711 \mathrm{bp}$. The sequences were $99-100 \%$ identical to $16 \mathrm{~S}$ rRNA gene sequences of $H$. felis (Genbank accession numbers AY366428, U51871, M57398, AY686607) in 15 dogs (79\%), H. salomonis (Genbank accession number Y09405) in two dogs (10.5\%), and Helicobacter sp. (Genbank accession numbers EF217412, AY634577) in two dogs (10.5\%). The phylogenetic tree constructed from these sequences showed two main clusters (Fig. 4). Eighteen out of 19 (95\%) dog samples clustered mostly with $H$. felis species, $H$. salomonis, and uncultured Helicobacter sp., while one dog sample (Dog-1) was the most divergent and clustered with other Helicobacter sp. Sequences from dogs were clearly separated from W. succinogenes ATCC 29543 (M88159). Of the three NHPH species detected, H. felis was most negatively correlated with both $H$. salomonis $(r=-0.577 ; p=0.007)$ and/or Helicobacter sp. $(r=-0.577 ; p=0.007)$.

\section{DISCUSSION}

A high prevalence (95\%) of gastritis was found in both sick and healthy pet dogs during our study. This agrees with other studies reporting the occurrence of gastritis as a common finding in $\operatorname{dogs}^{17,24}$. The gastritis in dogs is characterized by the presence of mild to moderate superficial 
POLANCO, R.; SALAZAR, V.; REYES, N.; GARCÍA-AMADO, M.A.; MICHELANGELI, F. \& CONTRERAS, M. - High prevalence of DNA from non-H. pylori helicobacters in the gastric mucosa of Venezuelan pet dogs and its histological alterations. Rev. Inst. Med. Trop. Sao Paulo, 53(4): 207-12, 2011.

Table 2

NHPH infection status as assessed by different tests

\begin{tabular}{|c|c|c|c|c|c|c|c|}
\hline \multirow[b]{3}{*}{$\begin{array}{l}\text { No. of dogs } \\
\text { with pattern }\end{array}$} & \multirow[b]{3}{*}{$\begin{array}{l}\text { Urease } \\
\text { testing }\end{array}$} & \multirow[b]{3}{*}{$\begin{array}{c}\text { Presence of } \\
\text { Bacteria } \\
\text { (H\&E and WS) }\end{array}$} & \multirow[b]{3}{*}{ FISH } & \multicolumn{4}{|c|}{ Fragment determined by PCR (bp) } \\
\hline & & & & \multirow{2}{*}{$\begin{array}{c}\text { Helicobacteraceae } \\
\text { 16S rRNA gene } \\
(764 \mathrm{bp})\end{array}$} & \multirow{2}{*}{$\begin{array}{c}\text { Helicobacter spp. } \\
\text { 16S rRNA gene } \\
\text { (399 bp) }\end{array}$} & \multicolumn{2}{|c|}{ H. pylori } \\
\hline & & & & & & $\begin{array}{l}\text { glm } M \text { gene } \\
294 \text { (bp) }\end{array}$ & $\begin{array}{l}\text { cagA gene } \\
128 \text { (bp) }\end{array}$ \\
\hline 1 & - & + & + & + & - & - & - \\
\hline 1 & - & + & + & + & + & - & - \\
\hline 17 & + & + & + & + & + & - & - \\
\hline 1 & + & - & - & - & - & - & - \\
\hline
\end{tabular}

H\&E, hematoxylin-eosin stain; WS, Warthin-Starry stain.
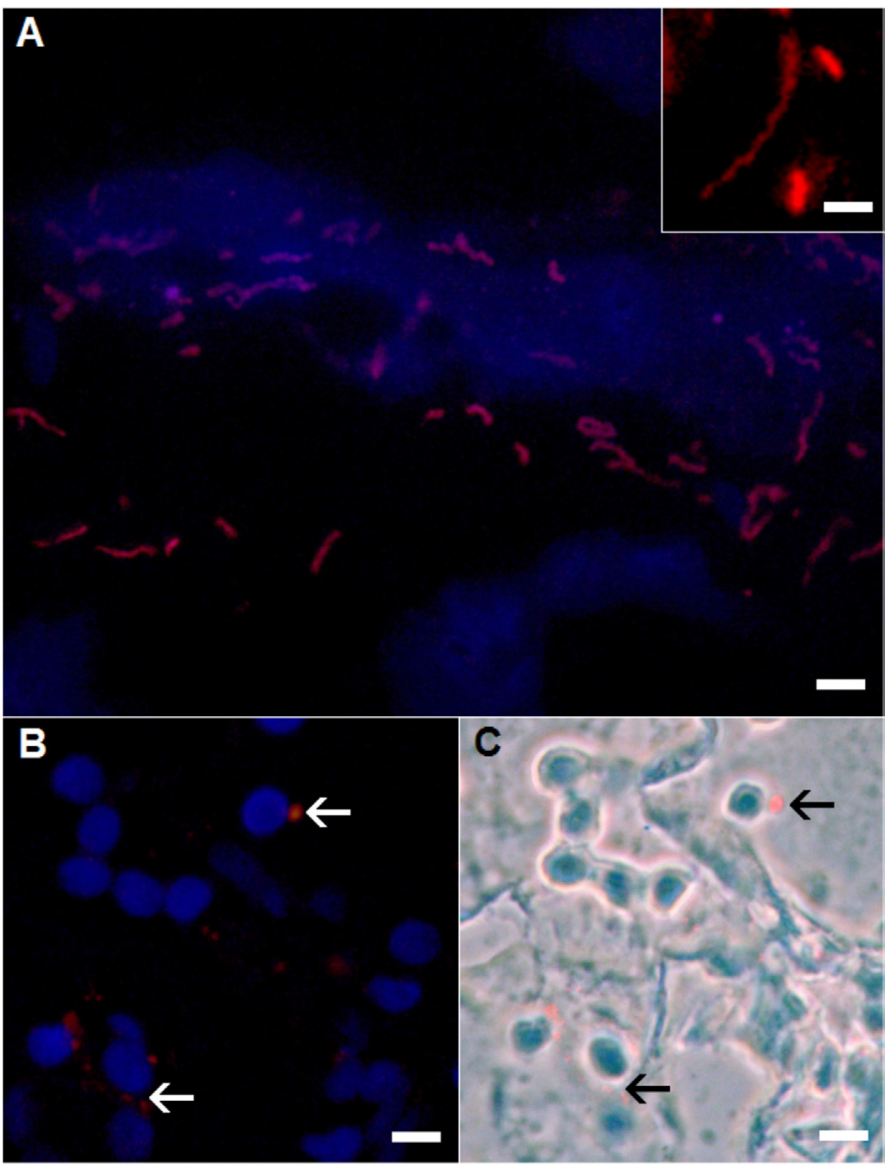

Fig. 3 - Detection of NHPH by FISH in gastric mucosa (fundus) tissue sections. (A) Detection of NHPH in the gastric mucosa (red stained); the nuclei were stained by DAPI (blue). The insert shows various morphologies of NHPH species. (B) Image of Helicobacteraceae adhering to mononuclear cells in the lamina propia (arrows). (C) Merge of fluorescence and phase contrast images, corresponding to the same section as in $\mathrm{B}$; arrow points to the same bacteria as in B. Bars: A: $10 \mu \mathrm{m}$; B and C: $5 \mu \mathrm{m}$; insert: $2.5 \mu \mathrm{m}$.

lymphoplasmocytic infiltrates, with atrophy and fibrosis ${ }^{33}$. Despite the high prevalence of gastritis in dogs, the cause of this mucosal lesion has not been clearly determined. Several factors for its development have

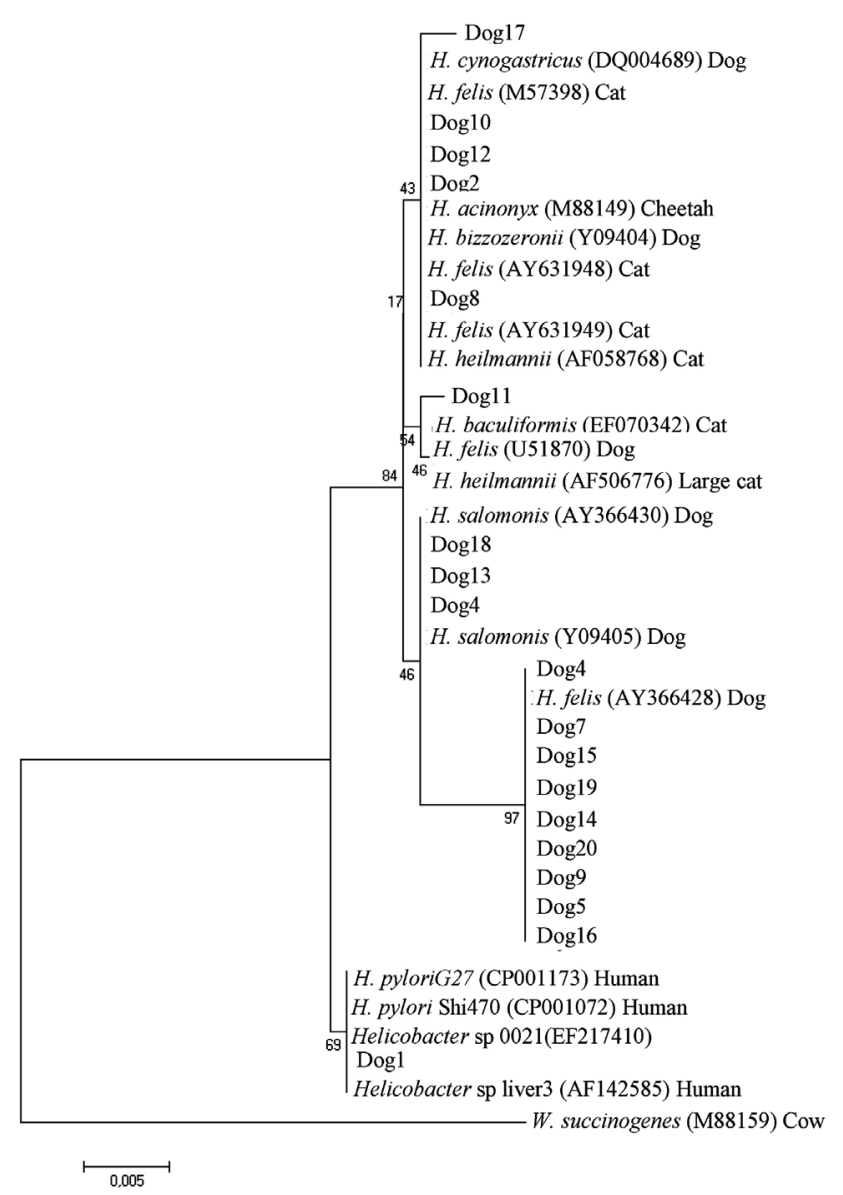

Fig. 4 - Phylogenetic consensus tree showing the genetic relationship of Helicobacteraceae 16S rRNA gene sequences amplified from 19 dogs to other Helicobacter. Scale bar represents a $1 \%$ difference in nucleotide sequence as determined by measuring the length of horizontal lines connecting any species. Accession numbers of sequences are given in brackets after each isolate name, and the species from which it was isolated except for Helicobacter sp. 0021.

been proposed, as systemic disease, ulcerogenic drugs, and host immune responses to parasites, dietary antigens, or bacterial components all may cause mucosal inflammation ${ }^{21}$. However, examination of fundic biopsies 


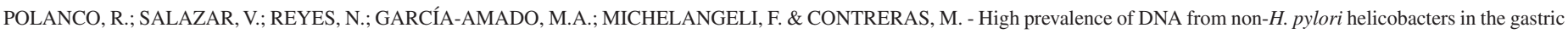
mucosa of Venezuelan pet dogs and its histological alterations. Rev. Inst. Med. Trop. Sao Paulo, 53(4): 207-12, 2011

revealed the colonization of spiral-shaped bacteria, suggesting a possible causal role for the bacteria.

In the present study, the NHPH infection was determined by at least three of four methods (urease test, histology, PCR and FISH). NHPH were identified in $95 \%$ of the dogs, which is in agreement with previous studies conducted on pet dogs, with a prevalence ranging from 67 to $86 \%$ in healthy animals, and 61 to $100 \%$ in those with vomiting ${ }^{14,19}$. NHPH infection was evidenced by Helicobacteraceae-and Helicobacter-specific PCR in 19 and in 18 of 20 dogs, respectively. Only one animal (Dog-1) was PCRpositive for Helicobacteraceae and PCR-negative for Helicobacter spp. Interestingly, the results of partial $16 \mathrm{~S}$ rDNA sequencing for Dog-1 is more closely related to Helicobacter spp., including $H$. pylori as shown in the phylogenetic tree (Fig. 4). However, the $H$. pylori specific genes glm $M$ and $\operatorname{cagA}$ were never detected in any of the dogs. The glm $M$ gene encodes phosphoglucosamine mutase, an enzyme catalyzing the interconversion of glucosamine-6-phosphate into glucosamine-1-phosphate ${ }^{7}$. The cagA gene of $H$. pylori is one of the most important virulence factors of this bacterium and is related to cytotoxin production, which is strongly associated with peptic ulcer disease and gastric cancer in humans ${ }^{32}$. This is consistent with another study in which $H$. pylori was not found in dogs, indicating that pet dogs may not represent a source or reservoir of H. pylori for the human population ${ }^{11}$. The $16 \mathrm{~S}$ rRNA PCR was specific and sensitive for detection of NHPH; results obtained with this method were in agreement with the visualization of NHPH in gastric biopsies by FISH. This technique is a powerful tool for the specific detection of Helicobacter within gastric tissue. It does not, however, allow identification to the species level of the dog and cat associated NHPH. Sequencing of the $16 \mathrm{~S}$ and $23 \mathrm{~S}$ ribosomal RNA encoding genes allows differentiation of $H$. suis from the other gastric non- $H$. pylori Helicobacter species, but it cannot distinguish between $H$. felis, $H$. bizzozeronii, $H$. salomonis, $H$. heilmannii s.s., $H$. cynogastricus and $H$. baculiformi s $^{14}$. Although for differentiation between these species, sequencing of the $h s p 60$ or gyrB gene is useful, sequencing of the ure $A$ and ure $B$ genes seems currently to be the most suitable method since sequences of these genes are available for all NHPH species ${ }^{15}$.

The identity of infecting NHPH species, using PCR with familyspecific primers, was determined in 19 of the 20 dogs. They contained approximately 600 to $711 \mathrm{bp}$ amplicons that shared $99-100 \%$ sequence identity with the $16 \mathrm{~S}$ rRNA genes of $\mathrm{H}$. felis, H. salomonis, and Helicobacter sp. as single infections. H. felis, H. bizzozeronii, $H$. salomonis, $H$. heilmannii s.s., H. cynogastricus and $H$. baculiformis represent a group of gastric NHPH species commonly found in dogs and cats which have recently been referred to as Helicobacter heilmannii s.1. ${ }^{15,27}$. These species are both phenotypically and phylogenetically highly related ${ }^{3,20,28}$, and some individual animals can often be infected by multiple gastric NHPH species ${ }^{28,31}$.

In summary, these results demonstrate the presence of NHPH DNA in the gastric mucosa of pet dogs from Venezuela. However, there was no correlation between the severity of gastritis and the presence of NHPH. Since the tests used here do not allow distinguishing between H. felis, H. bizzozeronii, $H$. salomonis, $H$. heilmannii s.s., H. cynogastricus and $H$. baculiformis, a possible association between a specific NHPH species and degree of gastritis remains to be studied.

\section{RESUMEN}

\section{Alta prevalencia de ADN de los helicobacteres no-H. pylori en la mucosa gástrica de perros domésticos venezolanos y sus alteraciones histopatológicas}

Los helicobacteres no- $H$. pylori (NHPH, por sus siglas en inglés) han sido demostrados como bacterias gástricas de forma espiral; sin embargo, sus roles en la patogénesis de la enfermedad gastrointestinal superior no han sido claramente establecidos. El propósito de este estudio fue evaluar la prevalencia de ADN de los NHPH en la mucosa gástrica de perros y su asociación con histopatología. Helicobacter fue detectado a través de técnicas histopatológicas, análisis de PCR y FISH en biopsias del fundus gástrico de 20 perros con o sin signos de enfermedad gastrointestinal. La PCR y FISH se basaron en secuencias parciales del gen ARNr 16S. Diecinueve perros mostraron gastritis leve a marcada en el fundus gástrico y sólo un perro tuvo una mucosa gástrica sana. El ADN de los NHPH fue detectado en 18 perros con gastritis y uno con mucosa gástrica normal. Sin embargo, no hubo correlación significativa entre la presencia de ADN de los NHPH y el grado de gastritis. Estos resultados demuestran una alta prevalencia de ADN de los NHPH en la mucosa gástrica de perros de Venezuela. Futuros estudios son necesarios para determinar la posible asociación entre una especie específica de los HNPH y el grado de gastritis.

\section{ACKNOWLEDGEMENTS}

This study was funded by the Instituto Venezolano de Investigaciones Científicas to M.C. and M.A.G-A, and by the Centro de Investigaciones Agropecuarias de la Universidad Nacional Experimental "Francisco de Miranda" grant CI.2007.039 to R.P.

\section{REFERENCES}

1. Amann RI, Krumholz L, Stahl DA. Fluorescent-oligonucleotide probing of whole cells for determinative, phylogenetic, and environmental studies in microbiology. J Bacteriol. 1990;172:762-70.

2. Baele M, Pasmans F, Flahou B, Chiers K, Ducatelle R, Haesebrouck F. NonHelicobacter pylori helicobacters detected in the stomach of humans comprise several naturally occurring Helicobacter species in animals. FEMS Immunol Med Microbiol. 2009;55:306-13.

3. Baele M, Van den Bulck K, Decostere A, Vandamme P, Hanninen ML, Ducatelle R, et al. Multiplex PCR assay for differentiation of Helicobacter felis, H. bizzozeronii, and H. salomonis. J Clin Microbiol. 2004;42:1115-22.

4. Bohr UR, Primus A, Zagoura A, Glasbrenner B, Wex T, Malfertheiner P. A groupspecific PCR assay for the detection of Helicobacteraceae in human gut. Helicobacter. 2002; 7:378-83.

5. Chan V, Crocetti G, Grehan M, Zhang L, Danon S, Lee A, et al. Visualization of Helicobacter species within the murine cecal mucosa using specific fluorescence in situ hybridization. Helicobacter. 2005;10:114-24.

6. Day MJ, Bilzer T, Mansell J, Wilcockx B, Hall E.J, Jergens A, et al. Histopathological standards for the diagnosis of gastrointestinal inflammation in endoscopic biopsy samples from the dog and cat: a report from the World Small Animal Veterinary Association Gastrointestinal Standardization Group. J Comp Path. 2008;138(suppl 1):S1-43.

7. De Reuse H, Labigne A, Mengin-Lecreulx D. The Helicobacter pylori ureC gene codes for a phosphoglucosamine mutase. J Bacteriol. 1997;179:3488-93. 
POLANCO, R.; SALAZAR, V.; REYES, N.; GARCÍA-AMADO, M.A.; MICHELANGELI, F. \& CONTRERAS, M. - High prevalence of DNA from non-H. pylori helicobacters in the gastric mucosa of Venezuelan pet dogs and its histological alterations. Rev. Inst. Med. Trop. Sao Paulo, 53(4): 207-12, 2011.

8. DeSantis TZ Jr, Hugenholtz P, Keller K, Brodie EL, Larsen N, Piceno YM, et al. NAST: a multiple sequence alignment server for comparative analysis of $16 \mathrm{~S}$ rRNA genes. Nucleic Acids Res. 2006;34(Web Server Issue):w394-9.

9. DeSantis TZ, Hugenholtz P, Larsen N, Rojas M, Brodie EL, Keller K, et al. Greengenes, a chimera checked 16S rRNA gene database and workbench compatible with ARB. Appl Environ Microbiol. 2006;72:5069-72.

10. Domínguez-Bello MG, Michelangeli F, Romero R, Beker B, Lara D, Morera C, et al. Modification of Christensen urease test as an inexpensive tool for detection of Helicobacter pylori. Diagn Microbiol Infect Dis. 1997;28:149-52.

11. Eaton KA, Dewhirst FE, Paster BJ, Tzellas N, Coleman BE, Paola J, et al. Prevalence and varieties of Helicobacter species in dogs from random sources and pet dogs: animal and public health implications. J Clin Microbiol. 1996;34:3165-70.

12. Fox JG. The non- $H$. pylori helicobacters: their expanding role in gastrointestinal and systemic diseases. Gut. 2002;50:273-83.

13. Germani Y, Dauga C, Duval P, Huerre M, Levy M, Pialoux G, et al. Strategy for the detection of Helicobacter species by amplification of 16S rRNA genes and identification of $H$. felis in a human gastric biopsy. Res Microbiol. 1997;148:315-26.

14. Haesebrouck F, Pasmans F, Flahou B, Chiers K, Baele M, Meyns T, et al. Gastric helicobacters in domestic animals and nonhuman primates and their significance for human health. Clin Microbiol Rev. 2009;22:202-23.

15. Haesebrouck F, Pasmans F, Flahou B, Smet A, Vandamme P, Ducatelle R. NonHelicobacter pylori Helicobacter species in the human gastric mucosa: a proposal to introduce the terms H. heilmannii sensu lato and sensu stricto. Helicobacter. 2011; doi: 10.1111/j.1523-5378.2011.00849.x.

16. Happonen I, Linden J, Saari S, Karjalainen M, Hanninen ML, Jalava K, et al. Detection and effects of helicobacters in healthy dogs and dogs with signs of gastritis. J Am Vet Med Assoc. 1998;213:1767-74.

17. Happonen I, Saari S, Castren L, Tyni O, Hanninen ML, Westermarck E. Occurrence and topographical mapping of gastric Helicobacter-like organisms and their association with histological changes in apparently healthy dogs and cats. Zentralbl Veterinarmed A. 1996;43:305-15.

18. Harbour S, Sutton P. Immunogenicity and pathogenicity of Helicobacter infections of veterinary animals. Vet Immunol Immunopathol. 2008;122:191-203.

19. Hwang CY, Han HR, Youn HY. Prevalence and clinical characterization of gastric Helicobacter species infection of dogs and cats in Korea. J Vet Sci. 2002;3:123-33.

20. Jalava K, On SL, Vandamme PA, Happonen I, Sukura A, Hanninen ML. Isolation and identification of Helicobacter spp. from canine and feline gastric mucosa. Appl Environ Microbiol.1998;64:3998-4006.
21. Jergens AE, Pressel M, Crandell J, Morrison JA, Sorden SD, Haynes J, et al. Fluorescence in situ hybridization confirms clearence of visible Helicobacter spp. associated with gastritis in dogs and cats. J Vet Intern Med. 2009;23:16-23.

22. Kansau I, Raymond J, Bingen E, Courcoux P, Kalach N, Bergeret M, et al. Genotyping of Helicobacter pylori isolates by sequencing of PCR products and comparison with the RAPD technique. Res Microbiol. 1996;147:661-9.

23. Moutinho FQ, Thomassian A, Watanabe MJ, Suzano SMC, Sequeira JL. Prevalência de helicobactérias e alterações na mucosa gástrica em cães saudáveis. Arq Bras Med Vet Zootec. 2007;59:1080-3.

24. Neiger R, Simpson KW. Helicobacter infection in dogs and cats: facts and fiction. J Vet Intern Med. 2000;14:125-33.

25. Rugge M, Busatto G, Cassaro M, Shiao YH, Russo V, Leandro G, et al. Patients younger than 40 years with gastric carcinoma: Helicobacter pylori genotype and associated gastritis phenotype. Cancer. 1999;85:2506-11.

26. Samarbaf-Zadeh AR, Tajbakhsh S, Moosavian SM, Sadeghi-Zadeh M, Azmi M Hashemi J, et al. Application of fluorescent in situ hybridization (FISH) for the detection of Helicobacter pylori. Med Sci Monit. 2006;12:CR426-30.

27. Smet A, Flahou B, D'Herde K, Vandamme PA, Cleenwerck IM, Ducatelle R, et al. Helicobacter heilmannii sp. nov., isolated from feline gastric mucosa. Int J Syst Evol Microbiol. 2011. doi:10.1099/ijs.0.029207-0.

28. Takemura LS, Camargo PL, Alfieri AA, Bracarense AP. Helicobacter spp. in cats association between infecting species and epithelial proliferation within the gastric lamina propria. J Comp Path. 2009;141:127-34

29. Tamura K, Dudley J, Nei M, Kumar S. MEGA4: Molecular Evolutionary Genetics Analysis (MEGA) software version 4.0. Mol Biol Evol. 2007;24:1596-9.

30. Trebesius K, Panthel K, Strobel S, Vogt K, Faller G, Kirchner T, et al. Rapid and specific detection of Helicobacter pylori macrolide resistance in gastric tissue by fluorescent in situ hybridisation. Gut. 2000;46:608-14.

31. Van den Bulck K, Decostere A, Baele M, Driessen A, Debongnie JC, Burette A, et al. Identification of non-Helicobacter pylori spiral organisms in gastric samples from humans, dogs, and cats. J Clin Microbiol. 2005;43:2256-60.

32. Weel JF, van der Hulst RW, Gerrits Y, Roorda P, Feller M, Dankert J, et al. The interrelationship between cytotoxin-associated gene A, vacuolating cytotoxin and Helicobacter pylori-related disease. J Infect Dis. 1996;173:1171-5.

33. Wiinberg B, Spohr A, Dietz HH, Egelund T, Greiter-Wilke A, McDonough SP, et al Quantitative analysis of inflammatory and immune responses in dogs with gastritis and their relationship to Helicobacter spp. infection. J Vet Intern Med. 2005;19:4-14.

Received: 11 March 2011

Accepted: 14 June 2011 